Sains Malaysiana 49(10)(2020): 2477-2486

http://dx.doi.org/10.17576/jsm-2020-4910-13

\title{
Evaluation and Optimization of a New Approach on Phenol Extraction from Real Water
}

(Penilaian dan Pengoptimuman Pendekatan yang Baharu untuk Memisahkan Fenol daripada Air Semula Jadi)

\author{
Nik Nur Atiqah Nik wee, Nur Irsalina Mohd Juber, Mohd Nor Faiz NorRrahim \& Noorashikin Md. \\ SALEH*
}

\begin{abstract}
Phenolic compounds are hazardous industrial wastes that can contaminate real water resources. Therefore, the removal of these compounds in order to reach acceptable levels before discharging becomes challenging. In this study, a combination method between dispersive liquid-liquid microextraction (DLLME) with high-performance liquid chromatography-UV detection at $280 \mathrm{~nm}$ with the isocratic condition was introduced as a new approach for separating phenol content in water samples. The optimized parameters that affect the extraction efficiency, such as type of solvents, the volume of extraction and dispersive, stirring speed of centrifuge and salt concentration were evaluated using response surface methodology (RSM). A central composite design (CCD) was used to investigate the effect of four independent variables parameters, as mentioned. The recovery value on the DLLME method for the water sample is in the range of 92.31 - 114.29\%. Based on the recovery obtained, the DLMME-HPLC-UV is a promising method for phenol extraction because it is simple, effective and produce a high percentage of the recovery.
\end{abstract}

Keywords: Dispersive liquid-liquid microextraction; high-performance liquid-chromatography-UV; phenol; response surface methodology; water sample

ABSTRAK

Sebatian fenol adalah sisa industri berbahaya yang boleh mencemari sumber air semula jadi. Oleh itu, penyingkiran sebatian ini daripada air untuk mencapai tahap yang selamat sebelum dilepaskan menjadi suatu perkara yang mencabar. Dalam kajian ini, gabungan kaedah mikroektraksi cecair-cecair serak (DLLME) dengan kromatografi cecair prestasi tinggi-pengesanan UV pada $280 \mathrm{~nm}$ dalam keadaan isokumen diperkenalkan sebagai pendekatan yang baru untuk memisahkan fenol yang terdapat di dalam sampel air. Untuk mengoptimunkan parameter yang mempengaruhi kadar kecekapan pengekstrakan, seperti jenis pelarut, jumlah pengekstrakan dan serakan, kelajuan pengadukan emparan dan juga kepekatan garam dinilai menggunakan kaedah permukaan tindak balas (RSM). Reka bentuk komposit pusat (CCD) digunakan untuk mengkaji kesan empat parameter pemboleh ubah bebas seperti yang dinyatakan. Nilai pemulihan kaedah DLLME untuk sampel air adalah dalam lingkungan 92.31\% - 114.29\%. Berdasarkan nilai pemulihan yang diperoleh, DLLME-HPLC-UV adalah kaedah yang menjanjikan untuk pengestrakan fenol kerana ia adalah mudah, berkesan dan dapat menghasilkan peratusan pemulihan yang tinggi.

Kata kunci: Fenol; kaedah permukaan tindak balas ; kromatografi cecair prestasi tinggi-pengesanan UV; mikroektraksi cecair-cecair serakan; sampel air

\section{INTRODUCTION}

Environmental issues mainly water pollution has been a major concern facing the world. Nowadays, variety of chemicals whose persistency along with their constant release into the environment raised concerns to their potential impact on wildlife and human health. In view of this, efforts have been made by researchers to introduce a new approach for water treatment (Yusoff et al. 2018).
Industrial, domestic, agricultural activities, and other environmental and global changes are the main sources of water pollution (Gupta et al. 2012; Mahdavi et al. 2018). Inorganic, organic, and biological wastes from nature are the types of water pollution issued in water pollutants (Ba-abbad et al. 2012). Heavy metals are highly toxic and carcinogenic. According to Mittal et al. (2009), nearly 20\% of dyes dispensed by textile industries dumped into water 
bodies are toxic and even carcinogenic to both animals and humans (Mittal et al. 2009). Based on Lua (2019), pesticides, polynuclear hydrocarbons (PAHs), detergents, oils, grease, formaldehyde, and phenols (Jiang et al. 2003; Norseyrihan et al. 2016) are examples of toxic organic pollutants. Phenols are widely used in industries as an intermediate in the productions of dyes, medicines, and pesticides (Ariffin et al. 2019). For aquatic life, phenol is lethal to fish at low concentrations and is listed as a priority pollutant by the US Environmental Protection Energy (EPA) (Abdelkreem 2013). Even at low concentrations, phenols are classified as a carcinogen and harmful to an organism (Yang et al. 2006). Phenol can actuate various reactions, cancer-causing nature, teratogenicity, and mutagenicity as exhibited in animals (Said et al. 2013). Therefore, an increase in the production of wastewater, the demand for removal of organic compounds, including phenols, has been increased (Jiang et al. 2003). Thus, an assortment of creative techniques for treatment of phenol is developed to remove undesirable phenol from water. Several methods have been developed to remove phenol from wastewater, including microbial degradation, chemical oxidation (Khalid et al. 2004), solvent extraction (Yang et al. 2006), and adsorption (Singh et al. 2008). One of the most extensively used methods for dissimilar compound analysis is high-performance liquid chromatography (HPLC). For example, in industry, HPLC is routinely used for the quality control of products, monitoring analytes in biological matrices and analysis in chemistry methods (Cabrera \& Lubda 2000) as well as verification of food pollutants or food additives (Pawliszyn 2003). Nowadays, HPLC becomes more frequently used as it is performed much faster and reduce analysis time in order to obtain a higher output.

The first step and possibly the most important for analytical process usually consists of an extraction procedure resulted in isolation and enrichment of components of interest from a sample matrix is sample preparation. Extraction can vary in degree of selectivity, speed, and convenience, which is not only based on the conditions used but also on the geometric configurations of the extraction phase (Pawliszyn 2003). Currently, dispersive liquid-liquid microextraction (DLLME) (Noorashikin et al. 2017), solid-phase extraction (SPE), and liquid-liquid extraction (LLE) are the sample preparation and preconcentration of the analytes from the sample matrix that been used in previous work for solvent extraction (Sohaimi et al. 2018).

As for LLE, it is widely used for sample preparation in the analytical chemistry field due to simplicity, convenience, and broad applicability. Unfortunately, LLE is a lack of time-consuming, expensive, and involved in vast amounts of toxic organic solvents that are not miscible with aqueous samples; it may be harmful to health and environment (Cai et al. 2007; Wu et al. 2009). SPE is simple, sensitive, time-efficient and solvent-free but SPE can still be too long, relatively pricy, and sometimes suffers from analytes breakthrough when large sample volumes are analysed (Marce \& Borrull 1998; Wu et al. 2009).

DLLME is a novel sample preparation offering high enrichment factors from low water samples. The performance of DLLME is also demonstrated by the ternary solvent system in which a mixture of two types of organic solvents known as disperser solvent and extraction solvent that quickly added into target aqueous sample solution (Liu et al. 2013). DLLME provides several advantages as compared to LLE and SPE are inexpensive, simple methods, rapid, and ease of method development (Jain et al. 2013) short extraction times and low cost (Rykowska et al. 2018). According to the previous study, DLLME is a diminished LLE that uses microliter volumes of the extraction solvent compared to the classic extraction techniques together with high extraction recovery and enrichment factors (Wu et al. 2009). SPE uses small amounts of solvents compared to LLE; however, it is costly. DLLME combined with HPLC first suggested by Zhang et al. (2011). It is a separation of the organic and aqueous phases that occurs based on their different densities without centrifugation. Recently, DLLME combined with HPLC-UV is used for the extraction and determination of BPA in a water sample (Rezaee et al. 2009). This reported shows that the DLLME combined with the HPLC-UV produce the good recoveries for the organic extraction (Noorashikin et al. 2017; Yusoff et al. 2018).

Response surface methodology (RSM) is a mathematical and statistical formula used in the development of an adequate functional relationship between the response of interest, $y$, and several associated control (input) variables donated by $\mathrm{x} 1, \mathrm{x} 2, \ldots \mathrm{xk}$ (Yousefzadeh et al. 2018). Thus, RSM enables the evaluation of the effects of various process variables with their interactions on responsible variables (Liyanapathirana \& Shahidi 2005; Silva et al. 2007). The general objective of the present work was to apply the RSM approach to optimize the extraction conditions. The optimized conditions were generated from the RSM were applied to the extraction procedure (experimental). The extraction of phenol from real water were performed and the percentage of recoveries were obtained.

\section{MATERIALS AND METHODS}

REAGENT AND STANDARD

The selected reagents, such as chloroform and methanol, were obtained from Fisher Scientific (UK). Phenol, 
acetonitrile (HPLC grade), dichloromethane (99\%), and sodium chloride salt $(\mathrm{NaCl})$ were purchased from Merck (Germany). Both ethanol and acetone were obtained from $\mathrm{HmbG}$ Chemical and Friendemann that were used as a dispersive solvent. Deionized water was used in the mobile phase obtained through the Millipore Milli-Q Plus water purification system. A $1000 \mathrm{mg} / \mathrm{L}$ standard solution of phenol was prepared in acetonitrile HPLC grade. The standard working solution of $1 \mathrm{mg} / \mathrm{L}$ was prepared by diluting with acetonitrile HPLC grade.

\section{INSTRUMENTATION}

The separation and determination of phenol were carried out with the waters HPLC UV-Vis detector system. The system consists of a pump, degasser, column oven, ultraviolet detector, auto-injector, and guard column. HPLC column C18 (100 × $4.6 \mathrm{~mm}$, Merck, Germany) was used for Waters HPLC. A mixture of water and acetonitrile $(50: 60 \mathrm{v} / \mathrm{v})$ at a flow rate of $1 \mathrm{~mL} \mathrm{~min}^{-1}$ was used as a mobile phase in isocratic conditions. The detection was performed at a wavelength of $280 \mathrm{~nm}$. A Sartorius centrifuge was used to accelerate the phase separation at 1000-5000 rpm.

\section{PROCEDURE FOR DISPERSIVE LIQUID-LIQUID MICROEXTRACTION (DLLME)}

Figure 1 shows the general procedure for the DLLME method, where $1 \mathrm{~mL}$ of sample solution was placed in a $15 \mathrm{~mL}$ centrifuge tube. Then, $1.5 \mathrm{~mL}$ of acetone, which was used as a dispersing solvent containing $750 \mu \mathrm{L}$ chloroform (extraction solvent) and $500 \mu \mathrm{L}$ of working phenol solution was injected into the sample. Under the optimized procedure, the cloudy solution was centrifuged at $300 \mathrm{rpm}$ for $5 \mathrm{~min}$ to obtain the desired formation of the two-layer phases, which are the solvent-rich phase and aqueous solution. Afterward, the volume of the solventrich phase (sediment) was measured and completely transferred into vials using a syringe and injected into the HPLC system for analysis.

\section{SELECTION OF EXTRACTION AND DISPERSIVE OF SOLVENTS}

Preliminary experiments were first carried out to identify the types of extraction and dispersive solvents. The selection of appropriate extraction solvent and dispersive solvent are two majors. In this study, two organic solvents (dichloromethane and chloroform) were evaluated for extractant. The extractant was selected on the basis of having a higher density than water and had a high extraction capability of the new compound. Meanwhile, three different organic solvents were selected as a dispersive solvent, namely acetone, methanol, and ethanol. The selection of dispersive solvent should have appropriate miscibility with both extraction solvent and sample solution in order to form a cloudy state. Considering the volume of sediment phase, dichloromethane in the presence of acetone as a dispersing solvent formed a low sediment phase volume, whereas the combination of acetone-chloroform formed a more stable two-phase system. In the case of methanol-dichloromethane and ethanol-chloroform, it was found that a two-phase system

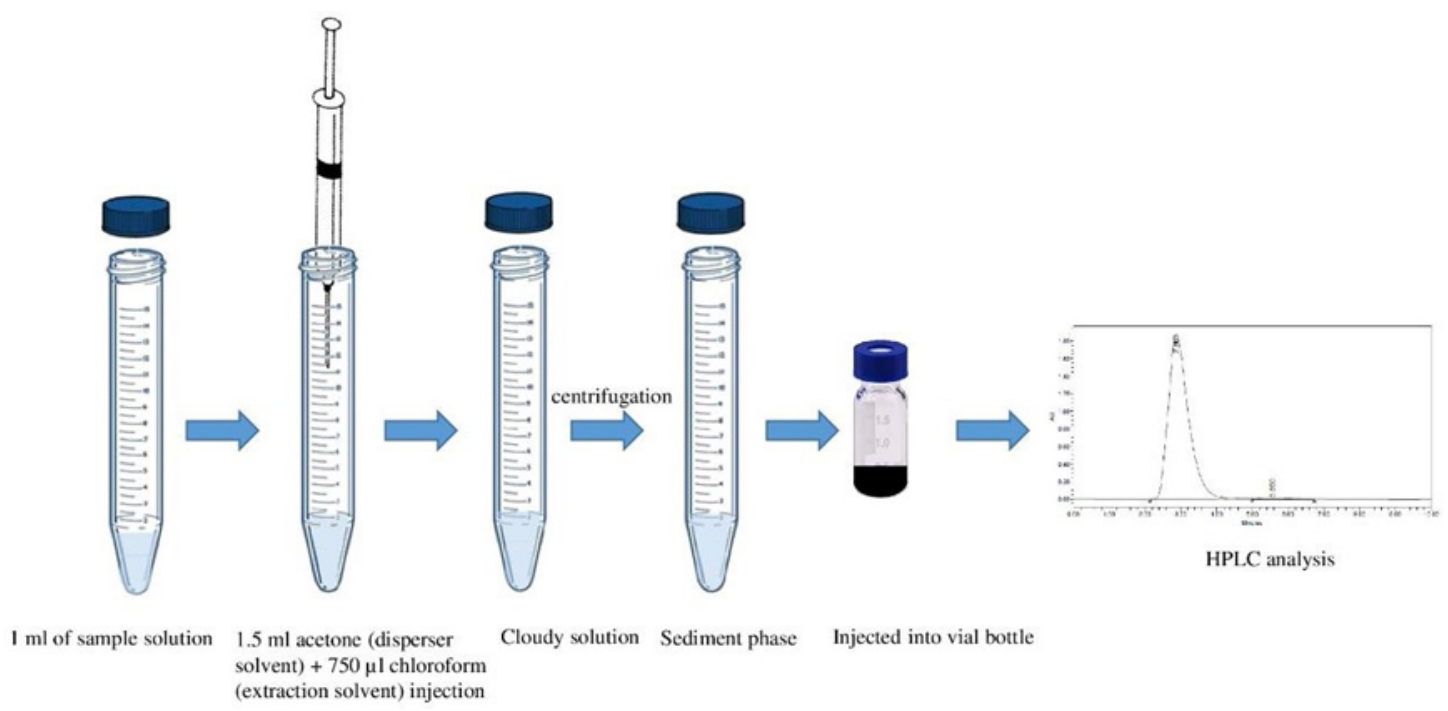

FIGURE 1. General procedure for DLLME 
was not formed. Thereby, chloroform was selected as the extraction solvent and acetone as a dispersive solvent for further studies.

\section{EXPERIMENTAL DESIGN}

Several factors may affect the response of DLLME, such as the volume of extractant and dispersive solvent, the concentration of salt, and the stirring speed of centrifugation. A four factors central composite design (CCD) was applied in the experimental design to study the responses with the centre point $(0,0)$, which was replicated 6 times, consisting of 30 experimental runs. The experimental design and data analysis were carried out using response surface methodology with the Design Expert Software version 10.0.7.

The optimization of phenol extraction from the water sample using RSM was to minimalize the number of experiments and reducing the cost of expensive analysis methods (Almeida et al. 2008). The statistical analysis was analyzed by the analysis of variance (ANOVA) and p-value, $P>0.05$ (not significant) showed the suggested model fit the experimental data, and independent variables influence the response (Azahar et al. 2017). The experiment was run in random order to avoid biased data. REGRESSION AND ANOVA ANALYSIS

Analysis of variance (ANOVA) was performed on Design Expert ${ }^{\circledR}$ software version 10.0.7.

\section{RESULTS AND DISCUSSION}

\section{OPTIMIZATION OF DLMME TECHNIQUE}

To achieve the optimum condition for determination of phenol with dispersive liquid-liquid microextraction (DLLME) procedure, the optimization of four important parameters; the volume of extractant (B), dispersive solvent (D), the concentration of salt (A) and stirring speed of centrifugation $(\mathrm{C})$, were selected as independent variables; and extraction recovery $(\mathrm{Y})$ was the dependent response variable. Table 1 shows the factors and levels for dispersive liquid-liquid microextraction (DLLME) of phenol. A total number of 30 experiments were carried out for the response

surface modelling. The analytical responses for optimization of DLLME method of phenol are depicted in Table 2.

TABLE 1. Factor and level for dispersive liquid-liquid microextraction of phenol

\begin{tabular}{|c|c|c|c|c|}
\hline Factor of independent variable & Symbol & Low Level & Central point & High level \\
\hline Volume of extractant solvent $(\mu \mathrm{L})$ & B & 500 & 750 & 1000 \\
\hline Volume of dispersive solvent $(\mathrm{ml})$ & $\mathrm{D}$ & 1 & 1.5 & 2 \\
\hline $\begin{array}{l}\text { Concentration of } \quad \text { salt } \\
(\mathrm{mol} / \mathrm{L})\end{array}$ & A & 0 & 1 & 2 \\
\hline Centrifugation & $\mathrm{C}$ & 1000 & 3000 & 5000 \\
\hline
\end{tabular}

Sodium chloride $(\mathrm{NaCl})$ is a salt that was used as the first variable factor on concentration, mol/L. According to Rezaee et al. (2009), the effect of adding salts on the extraction recovery of BPA was evaluated by the addition of $0-8 \%, w / v$ into the aqueous solution, and resulted in increased sediment phase. An increase in $\mathrm{NaCl} \%$ will increase the volume of the sedimented phase because of the decrease in solubility of the extractant solvents in the presence of salt. Meanwhile, Maham et al. (2014) used 0 $1.5 \mathrm{~mol} / \mathrm{L}$ in a concentration of salts to detect the saltingout through the extraction of phenol from lakes water samples. In conventional DLLME, water should have less density than the solvents of extraction, must have good extraction ability for a target analyte and low solubility in an aqueous sample. Based on previous research, an increase in the volume of salts would not have a significant effect on the efficiency of the extraction. In this research, the concentration of salts used are 0,1 , and $2 \mathrm{~mol} / \mathrm{L}$.

Extraction of solvents, centrifugation speeds, and dispersive of solvents were the other factors that have been tested in this study. The use of acetone as a dispersive of solvents increases the dilution of bisphenol in water (Rezaee et al. 2009). Table 2 shows the analytical for the optimization of DLMME of phenol extraction. 
TABLE 2. The analytical responses for optimization of DLLME method of phenol

\begin{tabular}{|c|c|c|c|c|c|}
\hline Run & $\begin{array}{c}\text { Factor A: } \\
\text { Concentration of salt } \\
(\mathrm{mol} / \mathrm{L})\end{array}$ & $\begin{array}{l}\text { Factor B: Extraction } \\
\text { solvent volume }(\mu \mathrm{L})\end{array}$ & $\begin{array}{c}\text { Factor C: } \\
\text { Centrifugation } \\
\text { speed (rpm) }\end{array}$ & $\begin{array}{l}\text { Factor D: Dispersive } \\
\text { solvent volume }(\mathrm{mL})\end{array}$ & $\begin{array}{l}\text { Extraction } \\
\text { recovery (\%) }\end{array}$ \\
\hline 1 & 0 & 500 & 5000 & 1 & 81.82 \\
\hline 2 & 1 & 750 & 3000 & 1.5 & 93.18 \\
\hline 3 & 0 & 500 & 1000 & 1 & 71.43 \\
\hline 4 & 1 & 750 & 3000 & 1 & 74.42 \\
\hline 5 & 0 & 1000 & 1000 & 1 & 118.75 \\
\hline 6 & 0 & 500 & 5000 & 2 & 100 \\
\hline 7 & 2 & 1000 & 5000 & 2 & 100.49 \\
\hline 8 & 2 & 500 & 5000 & 1 & 40 \\
\hline 9 & 0 & 1000 & 5000 & 1 & 118.75 \\
\hline 10 & 1 & 750 & 3000 & 1.5 & 80.85 \\
\hline 11 & 1 & 750 & 5000 & 1.5 & 73.47 \\
\hline 12 & 0 & 500 & 1000 & 2 & 100 \\
\hline 13 & 1 & 500 & 3000 & 1.5 & 53.85 \\
\hline 14 & 2 & 500 & 1000 & 1 & 37.25 \\
\hline 15 & 2 & 750 & 3000 & 1.5 & 80.85 \\
\hline 16 & 1 & 750 & 3000 & 1.5 & 84.71 \\
\hline 17 & 0 & 1000 & 1000 & 2 & 125 \\
\hline 18 & 2 & 100 & 1000 & 1 & 62.27 \\
\hline 19 & 2 & 1000 & 5000 & 1 & 81.82 \\
\hline 20 & 1 & 750 & 3000 & 1.5 & 84.24 \\
\hline 21 & 2 & 500 & 1000 & 2 & 43.29 \\
\hline 22 & 1 & 750 & 3000 & 1.5 & 80.85 \\
\hline 23 & 1 & 750 & 3000 & 1.5 & 97.67 \\
\hline 24 & 1 & 750 & 3000 & 2 & 90 \\
\hline 25 & 1 & 750 & 1000 & 1.5 & 66.67 \\
\hline 26 & 1 & 1000 & 3000 & 1.5 & 99.72 \\
\hline 27 & 2 & 1000 & 1000 & 2 & 100 \\
\hline 28 & 2 & 500 & 5000 & 2 & 80 \\
\hline 29 & 0 & 1000 & 5000 & 2 & 150 \\
\hline 30 & 0 & 750 & 3000 & 1.5 & 82.93 \\
\hline
\end{tabular}




\section{REGRESSION AND ANOVA ANALYSIS}

Analysis of variance (ANOVA) was performed on Design Expert ${ }^{\circledR}$ software version 10.0.7. This is a calculation technique and the main objective in this study, which is to estimate the relative contribution of each control factor to the overall response. ANOVA was also used to estimate variance errors and to determine the relative importance of various factors. It will show the effect of each of the factors investigated in the optimization criteria. The ANOVA analysis also indicated whether the observed change in response was due to changes in level adjustment or experimental standard errors. In the ANOVA analysis, squared regression (SS), degrees of freedom (DOF), squared mean (variance), and related F-test of significance (F-value) were calculated. The sources of variance that were found in the regression model are linear, quadratic, and two interaction factors. Model significance tests, lack-of-fit tests on regression models, and individual coefficients were also analyzed by ANOVA. In the RSM, if the $p$-value is lacking, $p>0.05$ (not significant), it states that the proposed model is in accordance with the experimental data, independent variables or parameters have a significant effect on the response (Alhaji et al. 2017). The quality of the model is explained by the determination of the coefficients of $R^{2}$ and $R^{2}$ adjusted ( $R^{2}$ adj). Table 3 shows the summary of the ANOVA analysis results.

TABLE 3. Summary of ANOVA analysis

\begin{tabular}{|c|c|c|c|c|c|}
\hline Source & $\begin{array}{l}\text { Degree of } \\
\text { freedom }\end{array}$ & Sum of squares & Mean square (variance) & F value $(\boldsymbol{\alpha}=0.05)$ & P-value \\
\hline Model & 14 & 15898.80 & $1135.63(8.77)$ & $<0.0001$ & significant \\
\hline A & 1 & 5749.64 & $5749.64(44.41)$ & $<0.0001$ & \\
\hline B & 1 & 6811.61 & $6811.61(52.61)$ & $<0.0001$ & \\
\hline $\mathrm{C}$ & 1 & 563.25 & $563.25(4.35)$ & 0.0545 & \\
\hline $\mathrm{D}$ & 1 & 2250.67 & $2250.67(17.38)$ & $<0.0008$ & \\
\hline Residual & 15 & 1941.94 & 129.46 & & \\
\hline \multicolumn{6}{|c|}{$\mathrm{R}^{2}=0.8912, \mathrm{R}^{2} \mathrm{adj}=0.7896$, Adequate Precision $=13.449$} \\
\hline
\end{tabular}

$Y=81.58-17.87 A+19.45 B+5.59 C+11.18 D-0.89 A B+1.44 A C+1.07 A D-0.36 B C+7.385 E-$ $003 B D+1.91 C D+5.65 A^{2}+0.54 B^{2}-6.17 C^{2}+5.97 D^{2}$

Based on Table 3, the standard deviation coefficient, $\mathrm{R}^{2}=0.8912$, shows the high model reliability in predicting the percentage of phenol preservation yield, where the model can explain $89.12 \%$ of the response variability. The small probability value $(\mathrm{p}<0.001)$ indicates that the model is highly significant and can be used to predict the response function accurately. Figure 2 illustrates the effect of salt concentrations, centrifugal speed, and volume of dispersive on the quadratic model obtained through Design Expert ${ }^{\circledR}$ 10.0.7. It is apparent from the results that the optimal condition of the variables to be carried out is determined by setting the phenol eigenvector to the micro-extraction method of dispersion fluid in the range of data obtained.

Figure 2(a) shows the interaction between the concentration of salt and centrifugal speed. It shows that high in centrifugal speed leads to a high concentration of salts. The optimization value for centrifugal speed is at $5000 \mathrm{rpm}$ while their concentration of salt is at 0.5 mol/L. Figure 2(b) shows the interaction between the concentration of salt and the extraction of the solvent. The extraction of phenol reached the optimum point with a salt concentration of $0 \mathrm{~mol} / \mathrm{L}$. Meanwhile, at a low concentration of salt, the volume of the extraction 
solvent reached the maximum level at $2000 \mu \mathrm{L}$. According to Pourbasheer et al. (2017) and Rezaee et al. (2006), increasing in salt concentration will reduce the solubility of the extraction solvent due to the presence of salt in the mixture. The effects of the volume of dispersive and centrifugal speed on phenol are shown in Figure 2(c). When the compressor speed was increased from 1000 rpm to $5000 \mathrm{rpm}$, and when the dispersive solvent also increased from 1 to $2 \mathrm{~mL}$, a high phenolic extraction yield produced was shown. The separation between the aqueous phase and the rich analytical phase occurred well at high compressor speed. This is because of the higher analytical density enables the removal of analytes from the aqueous phase to the rich analytical phase.
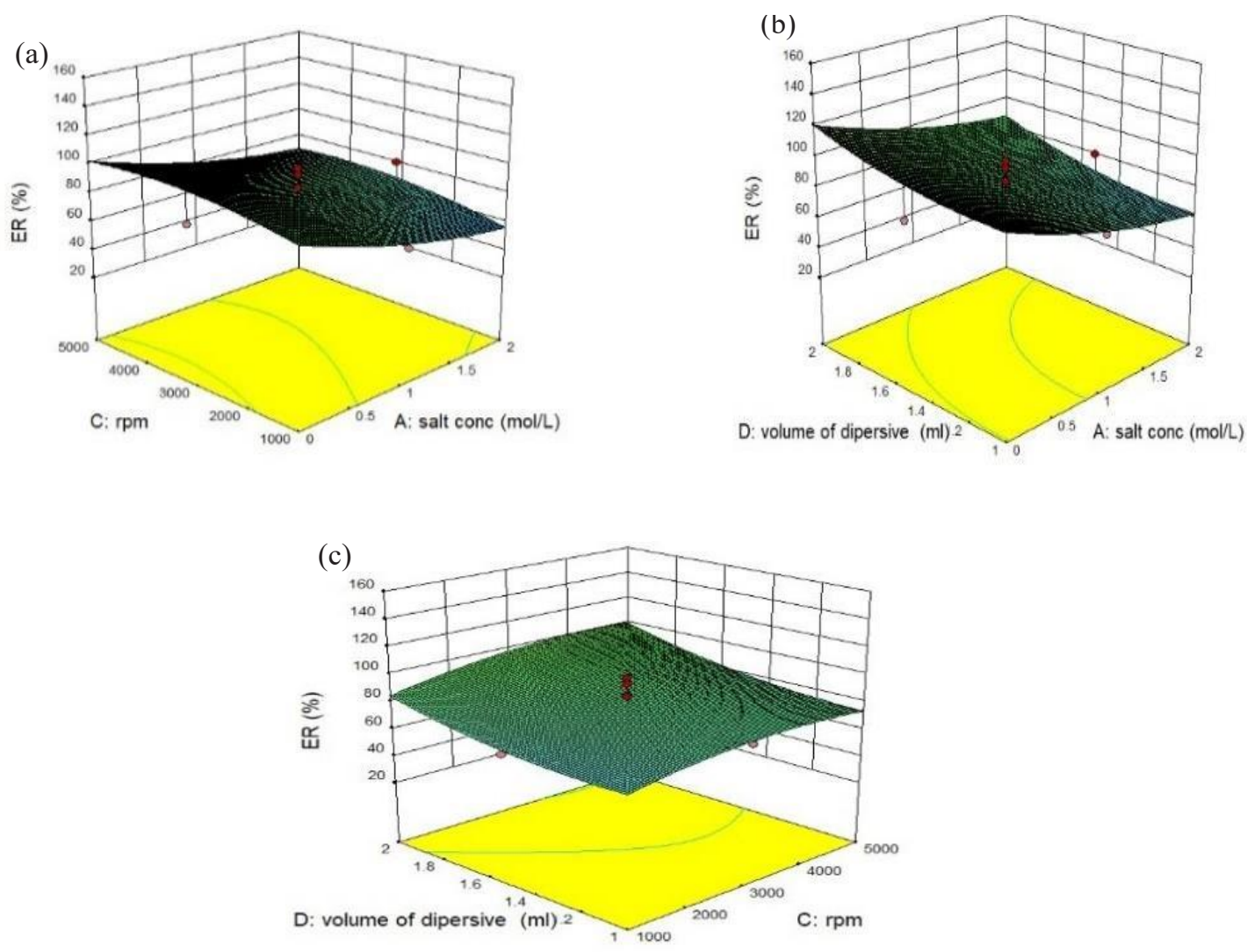

FIGURE 2. Three-dimensional response surfaces interaction between (a) centrifugal speed and salt concentration (b) volume of dispersive and salt concentration (c) volume of dispersive and centrifugal speed

\section{VALIDATION ON REAL SAMPLE}

The comparison of percentage recovery in water samples from rivers and lakes were carried out. Table 4 shows the results for the model's adequacy for predicting the recovery of phenol. Based on the optimum conditions, the recovery rate for the spiked samples was satisfactorily using the DLLME method of 92.31 and $114.29 \%$ for river water samples. Meanwhile, the recovery rate for lake samples is between 102.7-114.29\%. To determine the phenol content in the water samples, another DLLME analysis was carried out without adding (unspiked) 0.6 ppm phenol solution. The percentage of recovery (ER\%) as analytical responses was calculated based on the following equation:

$$
E R \%=\frac{V_{s e d}}{V_{a q}} \times \frac{C_{s e d}}{C_{o}} \times 100 \%
$$


where $V_{\text {sed }}$ and $V_{a q}$ are the volumes of sediment phase and volume of the aqueous sample solution, respectively. Whereas, $C_{\text {sed }}$ and $C_{o}$ are concentrations of the analyte in the sedimented phase and initial concentration of the analyte, respectively.

TABLE 4. Percentage recovery of phenol in water sample and concentration of phenol analysis based on DLLME method

\begin{tabular}{lcc}
\hline \multicolumn{1}{c}{ Water sample } & $\begin{array}{r}\text { Recovery (\%) in spiked } 0.6 \text { ppm water } \\
\text { sample }\end{array}$ & $\begin{array}{c}\text { Concentration of phenol in unspiked water } \\
\text { sample (ppm) }\end{array}$ \\
\hline Sg Langat & 114.29 & 12.156 \\
Sg Kuyoh & 114.29 & 16.255 \\
Sg Ramal & 92.31 & 11.103 \\
Sg Buah & 114.29 & 11.037 \\
Sg Kantan & 114.29 & 12.549 \\
Tasik Cempaka & 114.29 & 12.218 \\
Tasik FKAB, UKM & 114.29 & 13.534 \\
Tasik Seri Serdang & 102.70 & 11.999 \\
Tasik Bandar Tun Hussein Onn & 114.29 & 11.881 \\
Tasik Idaman, Dengkil & 102.70 & 13.131 \\
\hline
\end{tabular}

From Table 4, the results tested on the water sample showed all water samples contained phenol in the range of 11.037-16.255 ppm. Sg Kuyoh showed the highest amount of phenol contamination. The source of phenol pollution in Sg Kuyoh included wastewater from a residential area in Seri Kembangan. The lakes sample area showed that FKAB, UKM contained a high phenol concentration. According to this, it can be related to management activities surrounding the lake area that contributed to the contamination of the lake. DLLMEHPLC-UV technique has a good percentage of recovery for the determination of phenol in water samples. Figure 3 shows the result of the chromatogram of HPLC-UV spiked at $0.6 \mathrm{ppm}$ at $2.214 \mathrm{~min}$.

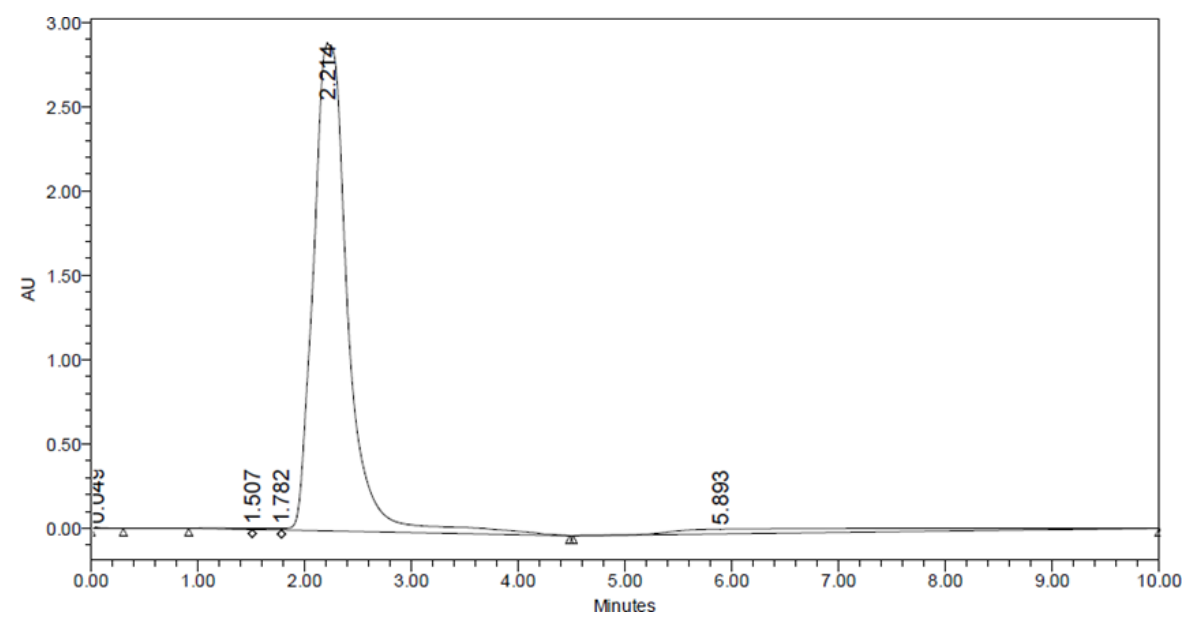

FIGURE 3. Chromatogram of HPLC-UV 


\section{CONCLUSION}

The influence of operating parameters, such as the volume of extraction solvents, dispersion solvent volume, salt concentration, and compressive velocity in the determination of phenol, were observed. The composite design (RSM) type of composite design (CCD) in Design Expert ${ }^{\circledR}$ 10.0.7 software was used to evaluate and optimize the operating parameters. The optimization was performed to determine the optimum conditions for the percentage of phenol yield set in the range. The model provided by Design Expert ${ }^{\circledR}$ 10.0.7 software based on the percent phenol yield is quadratic. The values of $\mathrm{R}^{2}$ and $\mathrm{R}^{2}$ adj for $\mathrm{Y} 1$ models are 0.8912 and 0.7896 , respectively. For the optimum conditions, the salt concentration was set as the minimum, while the other variables were in the range. This gave a high value, which is 1 . The percentage obtained by the model at optimum condition was $103.05 \%$ while the percentage for phenol tested in river and lake water samples was between 92.31 and $114.29 \%$. Compared with the other method, DLLME used organic solvent in a small volume. DLLME used to be more environmentally friendly, apart from that it is simple, fast, inexpensive and reduces in time.

\section{ACKNOWLEDGEMENTS}

We would like to express our gratitude to the Ministry of Higher Education, Malaysia for the Fundamental Research Grant Scheme FRGS/1/2018/STG01/UKM/02/23.

\section{REFERENCES}

Abdelkreem, M. 2013. Adsorption of phenol from industrial wastewater using olive mill waste. APCBEE Procedia 5(1): 349-357.

Alhaji, M.H., Abdullahi, M.S., Oparah, E.N., Bitrus, H. \& Rigit, A.R.H. 2020. Productiton of annins from Acacia nilotica pods for the leather manufacturing industryextractions, characterization, and optimization using design of experiment. Bioresources 15(2): 2212-2226.

Ariffin, M.M., Azmi, A.H.M., Saleh, N.M., Mohamad, S. \& Rozi, S.K.M. 2019. Surfactant functionalisation of magnetic nanoparticles: A greener method for parabens determination in water samples by using magnetic solid phase extraction. Microchemical Journal 147: 930-940

Azahar, N.F., Abd Gani, S.S. \& Mokhtar, N.F.M. 2017. Optimization of phenolics and flavonoids extraction conditions of Curcuma zedoaria leaves using response surface methodology. Chemistry Central Journal 11(1): 1-10.

Ba-Abbad, M.M., Kadhum, A.A.H., Mohamad, A.B., Takriff, M.S. \& Sopian, K. 2012. Synthesis and catalytic activity of $\mathrm{TiO}_{2}$ nanoparticles for photochemical oxidation of concentrated chlorophenols under direct solar radiation. International Journal of Electrochemical Science 7(6): 4871-4888.

Bezerra, M.A., Santelli, R.E., Oliveira, E.P., Villar, L.S. \& Escaleira, L.A. 2008. Response surface methodology
(RSM) as a tool for optimization in analytical chemistry. Talanta 76(5): 965-977.

Cabrera, K., Lubda, D., Eggenweiler, H.M., Minakuchi, H. \& Nakanishi, K. 2000. A new monolithic-type HPLC column for fast separations. Journal of High Resolution Chromatography 23(1): 93-99.

Cai, Y., Cai, Y.E., Shi, Y., Liu, J., Mou, S. \& Lu, Y. 2007. A liquid-liquid extraction technique for phthalate esters with water-soluble organic solvents by adding inorganic salts. Microchimica Acta 157(1-2): 73-79.

Gupta, V.K., Ali, I., Saleh, T.A., Nayak, A. \& Agarwal, S. 2012. Chemical treatment technologies for waste-water recycling - An overview. RSC Advances 2(16): 6380-6388.

Jain, R., Mudiam, M.K.R., Chauhan, A., Ch, R., Murthy, R.C. \& Khan, H.A. 2013. Simultaneous derivatisation and preconcentration of parabens in food and other matrices by isobutyl chloroformate and dispersive liquid-liquid microextraction followed by gas chromatographic analysis. Food Chemistry 141(1): 436-443.

Jiang, H., Fang, Y., Fu, Y. \& Guo, Q.X. 2003. Studies on the extraction of phenol in wastewater. Journal of Hazardous Materials 101(2): 179-190.

Khalid, M., Joly, G., Renaud, A. \& Magnoux, P. 2004. Removal of phenol from water by adsorption using zeolites. Industrial \& Engineering Chemistry Research 43(17): 5275-5280.

Liu, S., Xie, Q., Chen, J., Sun, J., He, H. \& Zhang, X. 2013. Development and comparison of two dispersive liquid-liquid microextraction techniques coupled to high performance liquid chromatography for the rapid analysis of bisphenol A in edible oils. Journal of Chromatography A 1295: 16-23.

Liyana-Pathirana, C. \& Shahidi, F. 2005. Optimization of extraction of phenolic compounds from wheat using response surface methodology. Food Chemistry 93(1): 47-56.

Lua, A.C. 2019. A detailed study of pyrolysis conditions on the production of steam-activated carbon derived from oil-palm shell and its application in phenol adsorption. Biomass Conversion and Biorefinery 10: 523-533.

Maham, M., Kiarostami, V., Waqif-Husain, S. \& Sharifabadi, M.K. 2014. Analysis of chlorpheniramine in human urine samples using dispersive liquid-liquid microextraction combined with high-performance liquid chromatography. Brazilian Journal of Pharmaceutical Sciences 50(3): 551557.

Mahdavi, S., Molodi, P. \& Zarabi, M. 2018. Functionalized $\mathrm{MgO}, \mathrm{CeO}_{2}$ and $\mathrm{ZnO}$ nanoparticles with humic acid for the study of nitrate adsorption efficiency from water. Research on Chemical Intermediates 44(9): 5043-5062.

Masqué, N., Marcé, R.M. \& Borrull, F. 1998. New polymeric and other types of sorbents for solid-phase extraction of polar organic micropollutants from environmental water. Trac Trends in Analytical Chemistry 17(6): 384-394.

Mittal, A., Kaur, D., Malviya, A., Mittal, J. \& Gupta, V.K. 2009. Adsorption studies on the removal of coloring agent phenol red from wastewater using waste materials as adsorbents. Journal of Colloid and Interface Science 337(2): 345-354.

Noorashikin, M.S., Norseyrihan, M.S., Nursyazwani, S., Husniyah, Z.A., Siti Rahmah, M.Z., Sangeetha, K. \& Karthi, S. 2017. The application of cloud point extraction in environmental analysis. J. Sustain. Sci. Manag. 12: 79-95. 
Noorashikin, M.S., Mohamad, S. \& Abas, M.R. 2016. Determination of parabens in water samples by cloud point extraction and aqueous two-phase extraction using highperformance liquid chromatography. Desalination and Water Treatment 57(47): 22353-22361.

Norseyrihan, M.S., Noorashikin, M.S., Adibah, M.S.N. \& Yusoff, F. 2016. Cloud point extraction of methylphenol in water samples with low viscosity of non-ionic surfactant Sylgard 309 coupled with high-performance liquid chromatography. Separation Science and Technology 51(14): 2386-2393.

Pawliszyn, J. 2003. Sample preparation: quo vadis? Analytical Chemistry 75(11): 2543-2558.

Pourbasheer, E., Qasemi, F., Rouhi, M., Azari, Z. \& Ganjali, M.R. 2017. Preconcentration and determination of 2 mercaptobenzimidazole by dispersive liquid-liquid microextraction and experimental design. Journal of Separation Science 40(11): 2467-2473.

Rezaee, M., Yamini, Y., Shariati, S., Esrafili, A. \& Shamsipur, M. 2009. Dispersive liquid-liquid microextraction combined with high-performance liquid chromatography-UV detection as a very simple, rapid and sensitive method for the determination of bisphenol A in water samples. Journal of Chromatography A 1216(9): 1511-1514.

Rezaee, M., Assadi, Y., Hosseini, M.R.M., Aghaee, E., Ahmadi, F. $\&$ Berijani, S. 2006. Determination of organic compounds in water using dispersive liquid-liquid microextraction. Journal of Chromatography A 1116(1-2): 1-9.

Rykowska, I., Ziemblińska, J. \& Nowak, I. 2018. Modern approaches in dispersive liquid-liquid microextraction (DLLME) based on ionic liquids: A review. Journal of Molecular Liquids 259: 319-339.

Said, M., Ahmad, A. \& Mohammad, A.W. 2013. Removal of phenol during ultrafiltration of Palm oil mill effluent (POME): Effect of $\mathrm{pH}$, ionic strength, pressure and temperature. Der Pharma Chemica 5(3): 190-196.

Silva, E.M., Rogez, H. \& Larondelle, Y. 2007. Optimization of extraction of phenolics from Inga edulis leaves using response surface methodology. Separation and Purification Technology 55(3): 381-387.

Singh, K.P., Malik, A., Sinha, S. \& Ojha, P. 2008. Liquid-phase adsorption of phenols using activated carbons derived from agricultural waste material. Journal of Hazardous Materials 150(3): 626-641.

Sohaimi, N.M., Saleh, N.M., Ariffin, M.M., Beh, S.Y. \& Ahmad, R. 2018. An environmentally friendly method for extraction of parabens in various samples using low viscosity and low cloud point temperature surfactant. Malaysian Journal of Analytical Sciences 22(3): 365-374.

Wu, Q., Li, Y., Wang, C., Liu, Z., Zang, X., Zhou, X. \& Wang, Z. 2009. Dispersive liquid-liquid microextraction combined with high performance liquid chromatographyfluorescence detection for the determination of carbendazim and thiabendazole in environmental samples. Analytica Chimica Acta 638(2): 139-145.

Yang, C., Qian, Y., Zhang, L. \& Feng, J. 2006. Solvent extraction process development and on-site trial-plant for phenol removal from industrial coal-gasification wastewater. Chemical Engineering Journal 117(2): 179-185.

Yousefzadeh, S., Matin, A.R., Ahmadi, E., Sabeti, Z., Alimohammadi, M., Aslani, H. \& Nabizadeh, R. 2018. Response surface methodology as a tool for modeling and optimization of Bacillus subtilis spores inactivation by $\mathrm{UV} /$ nano-Fe ${ }_{0}$ process for safe water production. Food and Chemical Toxicology 114: 334-345.

Yusoff, M.M., Yahaya, N., Saleh, N.M. \& Raoov, M. 2018. A study on the removal of propyl, butyl, and benzyl parabens via newly synthesised ionic liquid loaded magnetically confined polymeric mesoporous adsorbent. RSC Advances 8(45): 25617-25635.

Yusoff, F., Khing, N.T., Hao, C.C., Sang, L.P., Muhamad, N.A.B. \& Saleh, N.M. 2018. The electrochemical behavior of zinc oxide/reduced graphene oxide composite electrode in dopamine. Malaysian Journal of Analytical Sciences 22(2): 227-237.

Zhang, P.P., Shi, Z.G., Yu, Q.W. \& Feng, Y.Q. 2011. A new device for magnetic stirring-assisted dispersive liquid-liquid microextraction of UV filters in environmental water samples. Talanta 83(5): 1711-1715.

Nik Nur Atiqah Nik Wee, Nur Irsalina Mohd Juber \& Noorashikin Md. Saleh*

Department of Chemical and Process Engineering, CESPRO

Faculty of Engineering and Built Environment

Universiti Kebangsaan Malaysia

43600 UKM Bangi, Selangor Darul Ehsan

Malaysia

Mohd Nor Faiz Norrrahim

Research Center for Chemical Defence

Universiti Pertahanan Nasional Malaysia

Kem Sungai Besi

57000 Kuala Lumpur, Federal Territory

Malaysia

*Corresponding author; email: noorashikin@ukm.edu.my

Received: 16 January 2020

Accepted: 29 April 2020 